\title{
The Microrna-143/145 Cluster in Tumors: A Matter of Where and When
}

\author{
Valeria Poli *, Laura Seclì and Lidia Avalle * (D) \\ Molecular Biotechnology Center, Department of Molecular Biotechnology and Health Sciences, \\ University of Turin, Via Nizza 52,10126 Turin, Italy; laura.secli@unito.it \\ * Correspondence: valeria.poli@unito.it (V.P.); lidia.avalle@unito.it (L.A.); \\ Tel.: +39-11-6706428 (V.P.); +39-11-6706428 (L.A.)
}

Received: 26 February 2020; Accepted: 15 March 2020; Published: 17 March 2020

check for updates

\begin{abstract}
The establishment and spreading of cancer involve the acquirement of many biological functions including resistance to apoptosis, enhanced proliferation and the ability to invade the surrounding tissue, extravasate from the primary site, survive in circulating blood, and finally extravasate and colonize distant organs giving origin to metastatic lesions, the major cause of cancer deaths. Dramatic changes in the expression of protein coding genes due to altered transcription factors activity or to epigenetic modifications orchestrate these events, intertwining with a microRNA regulatory network that is often disrupted in cancer cells. microRNAs-143 and -145 represent puzzling players of this game, with apparently contradictory functions. They were at first classified as tumor suppressive due to their frequently reduced levels in tumors, correlating with cell survival, proliferation, and migration. More recently, pro-oncogenic roles of these microRNAs have been described, challenging their simplistic definition as merely tumor-suppressive. Here we review their known activities in tumors, whether oncogenic or onco-suppressive, and highlight how their expression and functions are strongly dependent on their complex regulation downstream and upstream of cytokines and growth factors, on the cell type of expression and on the specific tumor stage.
\end{abstract}

Keywords: miRNA-143; miRNA-145; tumorigenesis; EMT; oncogenes; oncosuppressors

\section{Introduction}

The process of tumorigenesis involves the dysregulation of many vital biological functions including cell proliferation, apoptosis, resistance to anoikis, acquirement of drug resistance features and, ultimately, of the ability to migrate, intravasate and extravasate at distant organ sites to give origin to metastases, which are the main cause of death for cancer patients [1]. A multitude of growth factors, hormones, protein-coding genes, and non-coding RNAs are involved in the fine regulation of these functions, which require coordinated activation and inactivation of specific genes. MicroRNAs (miR) are a class of conserved small non-coding RNAs (18-22 nucleotides), that function via base-pairing complementarity of their seed sequences (nucleotides 2-7) typically with the 3'UTR of target RNA, leading to inhibition of the target mRNA translation and often to its degradation [2]. MicroRNAs have important functions in finely regulating the expression of about $60 \%$ of the genes in mammals [3], and they have emerged as key players in cancer by targeting sets of functionally correlated genes, exerting both pro- and anti-oncogenic roles [4] acting both directly on tumor cells and on the pro-oncogenic/anti-oncogenic functions of stromal cells [5].

Among these, microRNA-143 and microRNA-145 have been shown to be often dysregulated in tumors (recently reviewed in reference [6]). These two evolutionarily conserved microRNAs are transcribed as a cluster from chromosome 5 in humans (5q33) and chromosome 18 in the mouse (18qE1), 
with their transcriptional units located at approximately $1.4 \mathrm{~kb}$ of distance. The two primary transcripts described are a bicistronic $11 \mathrm{~kb}$ RNA and a $1.9 \mathrm{~kb}$ smaller transcript containing miR-145 only [7,8]. Accordingly, their expression is mostly coordinated but miR-145 can also be transcribed independently under the positive control of tumor protein p53 (p53) [9], opposed to POU class 5 homeobox 1 (Oct4)-mediated repression [10] (Figure 1). The common regulatory elements lie in the $4.5 \mathrm{~kb}$ region upstream of miR-143, where binding sites for the serum response factor (SRF)/Myocd [7,11,12] and SMAD family member (SMAD) transcription factors [12] have been identified and characterized. Accordingly, SMAD-dependent transcriptional activation by transforming growth factor beta (TGF- $\beta$ ) plays a prominent role in controlling the expression of the cluster [12]. Despite related biological functions, these two microRNAs do not share sequence similarity and mostly recognize different sets of target genes [7,11-13], although they can synergistically regulate a subset of shared targets [14].

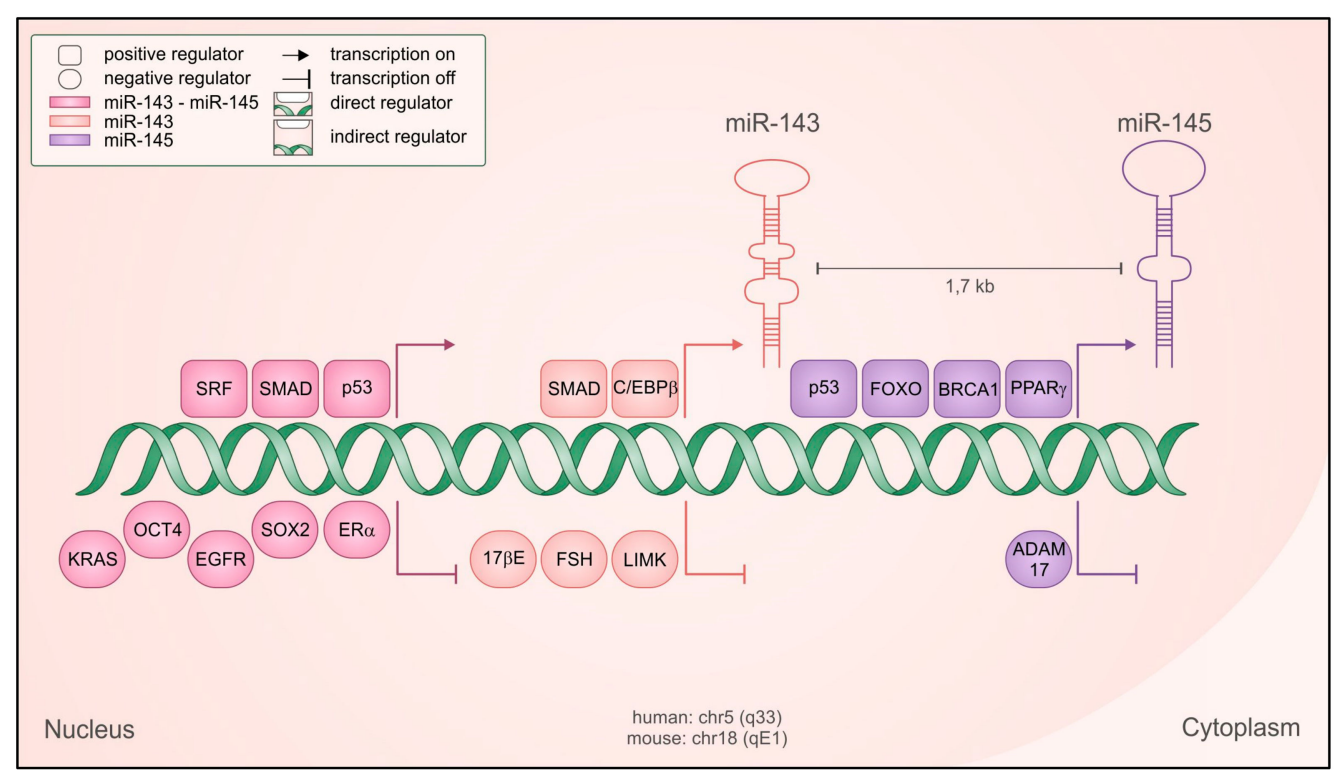

Figure 1. Regulation of miR-143 and -145 transcription. Schematic representation of the genetic locus containing the microRNAs, with both positive (squared) and negative (rounded) regulators shown to be relevant for their transcription, in both normal and cancer cells. Regulators with direct transcriptional activity are depicted closer to the DNA, and the color code indicates if they regulate both microRNAs as a cluster (fuchsia) miR-143 only (pink), miR-145 only (violet).

In human normal tissue a high expression of miR-143 and -145 has been described in cervix and colon, followed by prostate, uterus, small intestine and stomach, while very low expression was detected in kidney, placenta, testis, spleen, skeletal muscle, liver, and brain [8]. Both microRNAs have been characterized as key players in the differentiation of vascular smooth muscle cells (VSMC) during development $[10,11,13]$. Indeed, expression of the miR-143/145 cluster in adult mice was initially described as confined to visceral and vascular smooth muscle cells $[7,11,13]$, and their activity can alone induce the differentiation of multipotent neural crest stem cells into VSMCs, a well-known TGF- $\beta$-dependent form of EMT [11,15]. Vascular injury normally leads to dedifferentiation of SMCs, which then proliferate and migrate to the injury site giving origin to the neointima scar tissue that ultimately causes vascular obstruction [16]. This phenomenon requires miR-143 and -145 activity, since genetic inactivation of the miR-143/145 cluster in adult tissues leads to impaired neointima formation upon vascular injury $[7,13]$, correlating with disorganization of actin stress fibers and reduced migratory ability of miR-143 and -145-null SMCs [7]. Accordingly, both microRNAs functionally converge on the regulation of a significant number of common target genes ultimately modulating the activity of SRF and actin dynamics, and miR-143/145-null mice display arterial hypotension [7]. 
In the same vein, interference with miR-145 expression in zebrafish affects the contractility of intestinal SMCs, with consequent defects in gut peristalsis and swim bladder inflation [17].

Down-regulation of both miR-143 and -145 levels has frequently been observed in epithelial cancers and in B-cell malignancies [18]. Moreover, the locus is located in the 5q33 fragile site of human chromosome 5 that is often deleted in cancer [19], and ectopic expression of both microRNAs was reported to inhibit proliferation, induce apoptosis, and/or suppress anchorage-independent growth, epithelial to mesenchymal transition (EMT) and tumor-forming ability of different cancer cell types both in vitro and in vivo [6,16-19]. These evidences have led to consider both microRNAs as oncosuppressors, as recently reviewed by Das and Pillai [6]. Several reports later challenged this concept for both miR-143 and miR-145, showing that their expression correlated with invasion, disease grade and progression in specific types of tumors [20-23]. Thus, their role in cancer may be more complex than previously believed and possibly also depend on the cell type(s) of expression and on tumor stage, similar to what described for their inducer TGF- $\beta$ [24]. The ability to enhance tumor invasion and progression is in keeping with their prominent role in promoting migration and contractility of vascular and visceral smooth muscle cells $[7,17]$ and to induce epithelial wound healing with a paracrine mechanism [25]. Similar activities could be involved in supporting the pro-tumorigenic functions of cancer associated fibroblasts (CAFs), which have features of activated myofibroblasts, and in enhancing migration and invasion of epithelial tumor cells undergoing EMT. Here, we will review the main findings supporting the oncogenic versus the oncosuppressor roles of the two microRNAs, alone or in combination as a cluster, and discuss possible explanations for the contrasting results reported.

\section{Expression in Tumors}

As mentioned above, miR-143 and -145 have been found to be both down-regulated and up-regulated in tumors of different origins, suggesting that their role may vary according to tumor type and stage. Below we summarize the main findings in both directions with emphasis on their up-regulation, which has never been reviewed yet.

\subsection{Downregulation of miR-143/miR-145 in Tumors}

As recently reviewed by Das and Pillai [6], the downregulation of miR-143 and -145 was described in a considerable number of cancer cell lines and tumors, including those of the colon [26,27], prostate [28], ovary [29,30], bladder [31,32], breast [33,34], renal cell carcinoma [35], neuroblastoma [36], and osteosarcoma [37]. Moreover, lower expression rates of both microRNAs were reported to correlate with shorter disease-free survival and the presence of metastases in prostate, cervical and breast cancer, hepatocellular carcinoma (HCC) and glioma [6]. Human breast cancer cell lines were shown to express reduced levels of miR-143 and - 145 compared to the MCF10A immortalized normal epithelial cells and to normal tissue, and miR-145 but not miR-143 overexpression inhibited proliferation of several breast cancer cell lines [38].

In partial contrast, although the expression of the cluster in bladder cancer cells is generally lower than in the adjacent non-tumor tissue, high-grade muscle-invasive bladder tumors display higher expression of both microRNAs when compared to non-invasive or low grade samples, correlating with poor overall survival [39]. These data support previous evidence suggesting up-regulation of miR-143 and -145 expression correlating with poor survival in both invasive and non-invasive bladder cancer $[40,41]$.

How are miR-143 and -145 downregulated in tumors? While in myelodysplastic syndrome miR-143 and -145 downregulation is easily explained by genetic deletion, since the locus is located in the region of the often deleted 5q32 fragile site [19], the mechanisms are less clear in other tumor types. Genetic loss has also been detected in ovarian carcinomas [42], while epigenetic silencing via CpG island methylation of the miR-145 promoter was demonstrated in different tumors [43-45]. The transcriptional regulators peroxisome proliferator activated receptor gamma (PPAR $\gamma)$, CCAAT enhancer binding 
protein beta $(\mathrm{C} / \mathrm{EBP} \beta)$, forkhead box $\mathrm{O}$ (FoxO), BRCA1 DNA repair associated (BRCA1), and p53 have all been reported to positively regulate transcription of the cluster or of miR-145 alone [6] (Figure 1). Some of them are well known tumor suppressors whose downregulation in cancer may indirectly result in reduced miR-143 and -145 expression. Several oncogenic signals can inhibit the expression of the cluster, including the epidermal growth factor (EGF)/ epidermal growth factor receptor (EGFR) [46] signaling pathway and the oncogene KRAS, alone or in combination with MAPK or PI3K family members and acting via the Ras-responsive Element Binding Factor (REBB1) [47]. Additionally, follicle stimulating hormone (FSH), cortisol and 17-Beta-estradiol or its ERa receptor, often upregulated in cancer, were reported to repress the expression of both microRNAs in gastric, breast and ovarian cancer [6]. Interestingly, some of the factors shown to be involved in microRNAs repression are at the same time targets of either miR-143 (LIMK1, SOX2) or miR-145 (ADAM17, NEDD9, SOX2) [6] (Figure 1), potentially triggering a double negative feedback loop.

\subsection{Upregulation of $m i R-143 / m i R-145$ in Tumors}

Since 2007, discordant evidence started to emerge challenging the concept of miR143/145 microRNAs as solely onco-suppressive. In particular, their expression has often been correlated with enhanced motility, invasion, and metastasis, as outlined below and summarized in Table 1. Szafranska and colleagues reported overexpression of both microRNAs in samples from pancreatic ductal adenocarcinomas and pancreatitis, although their levels were below detection in 6 pancreatic cancer cell lines [48]. miR-143 levels were shown to positively correlate with metastases in Hepatitis B-related hepatocellular carcinoma patients, and its blockade was sufficient to inhibit metastasis in a transgenic mouse model of hepatic cancer [21]. In this vein, Fan and co-authors reported that the enhanced aggressiveness acquired by sphere-derived prostate cancer stem cells upon growth in adhesion functionally correlated with strongly increased miR-143 expression [49], the inhibition of which impaired their migration and invasion via increased expression of the tumor suppressor FIBRONECTIN TYPE III DOMAIN CONTAINING 3B (FNDC3B), a microRNA target. We have recently demonstrated that miRs-143 and -145 are strongly overexpressed in the highly aggressive mouse mammary tumors that develop in mice expressing the NeuT oncogene together with constitutively active STAT3 [50,51]. High expression was required for the disrupted cell junction phenotype displayed by derived NeuT-STAT3C cell lines, which could be normalized by silencing either microRNA. Inhibition of miR-143 significantly reduced in vivo extravasation of the NeuT-STAT3C cells, suggesting a key role in enhancing colonization at distant organs [50]. Moreover, overexpressing either microRNA in the normal murine mammary gland (NMuMG) cells increased cell motility, inducing the expression of several EMT markers, of TGF- $\beta$ targets and of junction proteins. The mechanism involved enhanced basal SMAD-mediated transcription, suggesting a positive feedback loop between miR-143 and the TGF- $\beta$ pathway. Of note, a negative feedback loop with TGF- $\beta$ has instead been proposed in hematopoietic stem cells (HSC). Mice lacking miR-143 and -145 displayed decreased long-term HSC numbers, predisposition to myeloproliferative activity and increased bone marrow expression of the common target gene an adaptor that facilitates the activation of SMADs, and this phenotype could be recapitulated by transplantation with DAB adaptor protein 2 (DAB2)-overexpressing HSCs into wild type mice [52]. Interestingly, increased DAB2 expression was also detected in HSCs from myelodysplastic syndrome patients presenting a deletion of the locus [52]. 
Table 1. Pro-tumorigenic functions of microRNA-143/145 cluster.

\begin{tabular}{|c|c|c|c|c|}
\hline MiR & Target Gene & Type of Cancer & Cancer-Related Function & Reference \\
\hline miR-143, miR-145 & n.d. & $\begin{array}{l}\text { Pancreatic ductal } \\
\text { adenocarcinoma }\end{array}$ & $\begin{array}{c}\text { Reduced in normal tissue compared } \\
\text { to tumor, not detected in tumor } \\
\text { cell lines }\end{array}$ & [48] \\
\hline miR-143 & $\begin{array}{l}\text { FIBRONECTIN } \\
\text { TYPE III DOMAIN } \\
\text { CONTAINING 3B } \\
\text { (FNDC3B) }\end{array}$ & $\begin{array}{l}\text { Hepatitis B related } \\
\text { hepatocellular } \\
\text { carcinoma } \\
\text { (HBV-HCC) }\end{array}$ & $\begin{array}{l}\text { Upregulated by NF-KB, promotes cell } \\
\text { migration, invasion and } \\
\text { tumor metastasis }\end{array}$ & [21] \\
\hline miR-143 & $F N D C 3 B$ & Prostate cancer & $\begin{array}{l}\text { Upregulated during cancer stem cell } \\
\text { differentiation, promotes metastasis }\end{array}$ & [49] \\
\hline $\operatorname{mir}-145$ & E-CADHERIN & Colorectal cancer & $\begin{array}{l}\text { When overexpressed in a metastatic } \\
\text { cell line, it increases cell growth and } \\
\text { leads to mesenchymal-like } \\
\text { cell morphology }\end{array}$ & [53] \\
\hline miR-145 & n.d. & $\begin{array}{l}\text { Esophageal } \\
\text { adenocarcinoma }\end{array}$ & $\begin{array}{l}\text { Do not affects cell proliferation, } \\
\text { accelerates wound closure, enhances } \\
\text { cell invasion, protects from anoikis }\end{array}$ & [20] \\
\hline miR-145 & stabilizes HSP27 & Colorectal cancer & $\begin{array}{l}\text { Associate with lymph node } \\
\text { metastasis. When overexpressed in } \\
\text { a CRC cell line, do not affects cell } \\
\text { proliferation, promotes migration and } \\
\text { invasion in vitro and in vivo }\end{array}$ & [22] \\
\hline miR-143, miR-145 & n.d. & Glioblastoma & $\begin{array}{c}\text { Highly expressed in typical areas of } \\
\text { invasion and in highly invasive GBM } \\
\text { subpopulations, when downregulated } \\
\text { invasion is reduced }\end{array}$ & [54] \\
\hline miR-145 & $s r G A P 1$ & Glioblastoma & Enhances invasiveness & [55] \\
\hline miR-143, miR-145 & $\begin{array}{c}\text { Proposed: CREB1, } \\
\text { MEKK2 }\end{array}$ & Mammary tumor & $\begin{array}{l}\text { Induces EMT features, enhances } \\
\text { cell migration }\end{array}$ & [50] \\
\hline
\end{tabular}

miR-145 expression is upregulated in primary colorectal cancer with lymph node metastasis. Indeed, although both metastatic and non-metastatic samples displayed miR-145 downregulation as compared to the normal tissue, its expression was significantly higher in the samples derived from metastatic patients. miR-145 overexpression promoted CRC cell migration in vitro and enhanced metastasis in vivo, with no effect on cell proliferation. The effect on cell motility was brought about by miR-145-mediated stabilization of heat shock protein (HSP) 27 [22]. In agreement with the idea that the specific role of tumor players may change according to disease stage, miR-145 (but not miR-143) was shown to promote EMT and increased anchorage-independent growth when overexpressed in a metastatic CRC cell line [53], and to be induced by neoadjuvant therapy in esophageal adenocarcinoma (EAC), where its levels correlated with a decreased disease-free survival [56]. Interestingly, miR-145 overexpression could lead to opposite effects in different types of esophageal cancer. miR-145 levels are normally downregulated in esophageal squamous cell carcinoma (ESCC), where its overexpression can inhibit cell proliferation and invasion [57,58]. In contrast, in esophageal adenocarcinoma (EAC) high miR-145 expression levels correlate with poor prognosis, enhancing cell invasion, adhesion to fibronectin and resistance to anoikis [20]. Finally, glioblastoma cells selected to become more invasive and aggressive display greatly increased levels of both miR-143 and - 145 without reduced cell viability [54], and miR-145 inhibition reduces their in vitro invasion [54]. These effects were attributed to miR-145-mediated downregulation of SLIT-ROBO RHO GTPase activating protein 1 , which carries miR-145 seeds [59].

How is the cluster up-regulated in tumors? One of the best characterized inducers of the miR-143/-145 cluster that is often induced during tumorigenesis is TGF- $\beta$, acting via SMAD factors both at the transcriptional and post-transcriptional level $[12,50,60]$. TGF- $\beta$ has a well-known dual role in cancer $[15,61]$, initially suppressing tumorigenesis via its anti-proliferative actions, while later driving metastasis thanks to its strong ability to induce epithelial to mesenchymal transition (EMT), cell motility and invasion $[61,62]$. This is well in line with the differential effects exerted by both microRNAs in late-stage, aggressive tumors vs early tumors with a good-prognosis (Figure 2). Another transcription 
factor often up-regulated in tumors and able to activate miR-143 is Liver-enriched Activator Protein $\mathrm{LAP}$, the full-length $\mathrm{C} / \mathrm{EBP} \beta$ isoform, which is known to promote pro-survival pathways upon ER stress correlating with enhanced drug resistance of triple negative breast cancer [63].

Finally, several functional single nucleotide polymorphisms (SNPs) have been identified in the regulatory regions of the two microRNAs, with most of the tested variants correlating with lower transcriptional activity and increased tumor risk. Li and co-authors first described several SNPs in the regulatory region of the miR-143/145 cluster, several positively correlating with CRC development [64]. The rs353292 variant, which displays reduced transcriptional activity in a Luciferase reporter assay [65], was shown to correlate with lower miR-143, but not miR-145, expression levels and CRC development in tumor samples. Similar findings were reported in the context of the rs4705342T $>\mathrm{C}$ and the rs4705343T > C variants, with the T alleles displaying reduced promoter activity and increased prostate cancer or cervical squamous cell carcinoma development [66,67]. A few SNPs correlating with reduced transcription and lower cancer risk have also been described, as in the case of the rs353293 allele in the cluster's promoter, which dictates lower transcriptional activity of a luciferase reporter and was a protective genetic marker in bladder cancer [68].

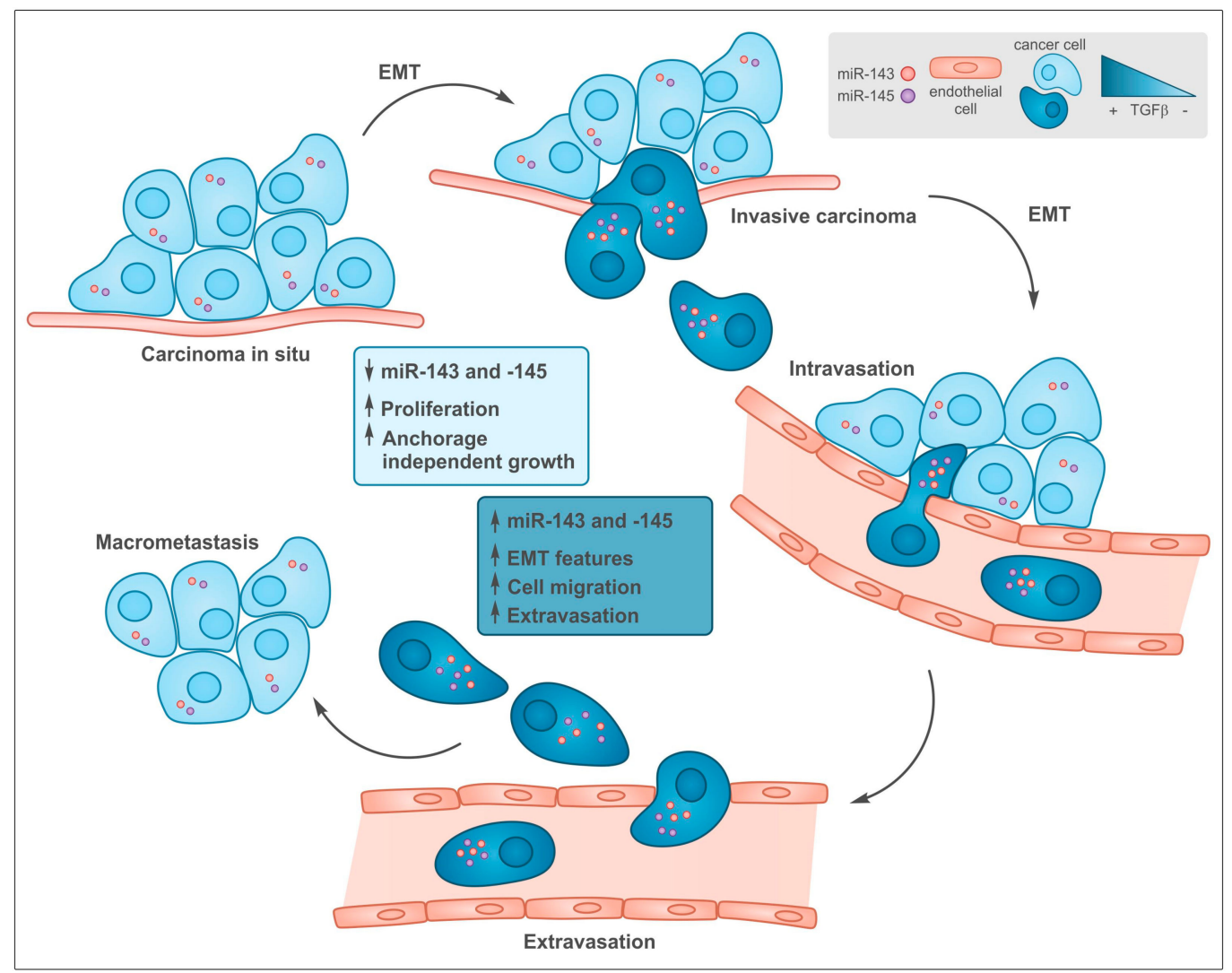

Figure 2. Common functions of transforming growth factor beta (TGF- $\beta$ ) and miR-143 and -145 during tumor progression. In early stages low levels of both TGF- $\beta$ and miR-143/145 are required to allow cell proliferation at the primary sites. During tumor progression, some cells undergo epithelial to mesenchymal transition (EMT), which is induced by TGF- $\beta$ that, among many other targets, triggers the up-regulation of miR-143 and -145 expression, which in turn, support tissue invasion and metastasis formation.

\section{Potential Mechanisms Mediating microRNAs Functions in Tumors}

Although anti-proliferative effects of miR-143 and -145 have been described, both microRNAs have mainly been involved in the control of multiple aspects related to the metastatic process via the regulation of EMT, which is believed to play a key role in the ability of tumor epithelial cells to acquire 
mesenchymal features that enable them to extravasate, survive in the circulation, intravasate at distant organs and grow to give origin to metastatic lesions [69,70] (Figure 2). Below we review the main data describing the role of miR-143 and -145 in regulating the EMT and EMT-related processes (Section 3.1), and the known target genes that could mediate their functions (Section 3.2).

\section{1. $\mathrm{miR}-143$ and -145 and EMT}

Indeed, many studies have investigated the ability of the two microRNAs to regulate cell movement and adhesion in the context of EMT and metastasis formation. Despite them being well-known transcriptional targets of the EMT driver TGF- $\beta$ [12], and despite their physiological role in the induction of EMT-like phenomena such as the differentiation of contractile and migrating SMCs, the majority of studies in tumors report a repressive role in EMT.

The expression of both miR-143 and miR-145 is reduced in esophageal squamous cell carcinoma clinical samples [71,72], where their overexpression was shown to downregulate mesenchymal markers, reducing cell migration and metastatic ability [71,72]. miR-145 ectopic expression inhibited cell migration by reducing the levels of FASCIN1 (FSCN1), an actin bundling protein involved in cytoskeletal dynamics, and regulating several EMT features in several breast cancer cell lines [73]. The upregulation of miR-143 in a similar context increased E-CADHERIN mediated cell-cell adhesion while reducing the expression of mesenchymal markers and cell migration [74].

Several components of the TGF- $\beta$ pathway itself have been proposed to be targeted by miR-143 and -145 , suggesting that they may take part in a negative feedback loop. miR-145 levels are reduced in tumor samples and cell lines with respect to normal tissue in non-small cell lung cancer and inversely correlated with those of SMAD3, one of the key transcription factors involved in TGF- $\beta$ responses and later characterized as a direct miR-145 target [75]. Indeed, overexpression of miR-145 was sufficient to reduce TGF- $\beta$-induced EMT in this cell model. Similarly, in a model of nasopharyngeal cancer miR-145 is downregulated, correlating with high SMAD3 levels and increased cell migration [76]. ACTIVIN A, a cytokine of the TGF- $\beta$ superfamily that contributes to SMAD2 and SMAD3 activation, is targeted by miR-143 and miR-145 in a model of oral squamous cell carcinoma [77]. In patient samples, low microRNAs expression correlates with high ACTIVIN A levels and poor prognosis. As already described in Section 2.2, moreover, both microRNAs can target the TGF- $\beta$ facilitator DAB2 in bone marrow stem cells [52].

The transcription factors zinc finger E-box homeobox 1 (ZEB1) and 2 (ZEB2) are involved in EMT induction by repressing epithelial genes such as E-CADHERIN, MUCIN (MUC) 1, PLAKOPHILIN 2, CONNEXIN 26, TIGHT JUNCTION PROTEIN 3 (ZO-3) [78]. Both are targeted by the miR-200 family, which is often downregulated in tumor EMT [79] resulting in their up-regulation [80]. In prostate cancer, ZEB2 was shown to be involved in a double negative feedback loop with miR-145 [81], and indeed ZEB2 and miR-145 levels are negatively correlated in prostate cancers. Moreover, miR-145 overexpression in DU145 prostate cancer cells could downregulate the mesenchymal markers N-CADHERIN, VIMENTIN and FIBRONECTIN while increasing E-CADHERIN levels [81,82]. Similar results were obtained in PC3 prostate cancer cells by Peng and colleagues, who showed that miR-143 and -145 levels were lower in samples from bone metastatic lesions that in primary prostate cancers, suggesting that their downregulation might help cells to undergo EMT and escape from the primary site [83]. ZEB2 emerged as a target of miR-145 also in cervical cancer cells, resulting in a reduction in VIMENTIN and SNAIL, upregulation of E-CADHERIN and reduced migration and invasion [84]. Interestingly, Lei and co-authors reported that the long non-coding (lnc) RNA TUG1, often overexpressed in papillary thyroid and bladder cancer, can act as a competing endogenous RNA for miR-145, resulting in the induction of its targets ZEB1 and ZEB2 and enhanced EMT [85,86]. Also the lncRNA UCA1 was shown to induce EMT by repressing miR-145 expression, leading to increased levels of ZEB1, ZEB2, and FSCN1 [87].

Paradoxically, most data supporting pro-tumorigenic functions of the two microRNAs also correlate their activity with enhanced cell movement and metastasis, although not always specifically 
investigating EMT. Fan and co-authors reported a direct correlation between in vitro and in vivo prostate cancer cells motility and the expression levels of miR-143, whose inhibition reduced migration and invasion [49]. miR-145 overexpression promoted CRC cell migration, EMT, enhanced anchorage-independent growth in vitro [53] and metastasis in vivo, with no effect on cell proliferation [22]. Increased cell invasion, adhesion to fibronectin and resistance to anoikis were observed in Esophageal Adenocarcinoma [20]. On the other hand, miR-145 inhibition limited in vitro glioblastoma cells invasion [55]. In the context of non-small cell lung cancer, Yang and colleagues showed that TGF- $\beta$-induced miR-145 reduced the expression of miR-20a by targeting c-myc, resulting in enhanced expression of its target transforming growth factor beta receptor II TGFBRII and sensitizing cells to TGF- $\beta$ treatment [88]. Similarly, interference with miR-143 in aggressive mouse mammary tumor cells diminished their motility and in vivo extravasation, correlating with increased SNAIL and ZO1 expression [50]. Accordingly, miR-143 or -145 overexpression in NMuMG mouse mammary epithelial cells increased their motility [50], correlating with enhanced activity of a SMAD-reporter gene, increased expression of the EMT markers Snail and N-cadherin and downregulation of the epithelial markers E-CADHERIN, ZO1, ZO3, and OCCLUDIN. Transcriptomic analysis revealed significantly overlapping patterns of down-regulated genes, including several transcription factors involved in regulating the ZO1, ZO3, and OCCLUDIN promoters. Moreover, downregulation of the putative miR-143/145 common target $M E K K 2$ could explain the observed decreased activation of ERK/MEK kinases, which are known to stabilize TGIF, a SMAD transcriptional co-repressor whose protein levels are reduced in the overexpressing cells. In turn, reduced TGIF levels may trigger the observed increased activity of the TGF- $\beta$ pathway [50].

\subsection{Proposed and Validated Targets of the microRNAs}

This host of observations suggests that miR-143 and miR-145 role in cancer may vary according to cell type and tumor stage, likely due at least in part to the differential repertoire of target genes in different cell types both of tumor and stromal origin, and at different stages of tumor progression. The shifting balance and abundance of targets, varying the competing endogenous RNA milieu, may influence the susceptibility of specific mRNAs [89]. Additionally, the expression of miR-143 and -145 is regulated by cytokines, hormones and growth factors whose relative abundance vary during tumor progression [6], as described for TGF- $\beta$ in session 3. It is therefore not surprising that contrasting data have also been published concerning the role of the two microRNAs in cell movement and EMT, as outlined in the previous section.

Despite the observation that the two microRNAs share a number of targets, suggesting at least partially converging functions, they do not show any sequence similarity and mostly recognize different sets of target genes, some of which exhibit oncogenic properties. miR-145 was shown to directly target oncogenic/stem cells factors such as C-MYC (downstream of P53 [9,90]),KRUPPEL LIKE FACTOR 4 (KLF4), SRY-BOX TRANSCRIPTION FACTOR 2 (SOX2), and OCT4 [10]. The latter is also a miR-145 transcriptional inducer, suggesting an OCT4-miR-145 negative feedback loop regulating the balance between pluripotency and differentiation. Moreover, genes involved in cell death, proliferation, cell cycle, gene expression and cancer have been described as miR-145 targets, including the non-receptor Tyrosine Kinase YES1 and the transcription factor STAT1 [91]. miR-143 and 145 share tumor growth-related target RNAs such as the oncogene KRAS and RREB1 (Ras-responsive element-binding protein) [92-95]. As to miR-143, it was shown to target the mitogen-activated protein kinase 7 (ERK5) [96-100], contributing to the inhibition of prostate cancer progression in mice [96]. More recently, the TGF- $\beta$ activated kinase 1 (TAK1), involved in controlling the activation of p38 MAPK, has also been reported as a miR-143 target in human ovarian cancer cells [101]. Finally, proteins involved in cell-cell adhesion and cell motility can be targeted by both microRNAs. For example, the cell-cell adhesion protein JAM-A [102] and the actin bundling protein FSCN1 [55,72,102-105] have both been described as miR-145 targets, suggesting inhibition of cell adhesion and movement. Indeed, overexpression of miR-145 in breast cancer cell lines decreased actin stress fibers, and miR-143 was shown to regulate 
ADDUCIN 3 [106] and FIBRONECTIN [21,49], leading to reduced cell migration. In contrast, NF-KB-induced miR-143 expression, leading to FIBRONECTIN downregulation, was linked to enhanced cell motility and metastasis in HBV-induced hepatocellular carcinomas [45] and in a prostate cancer model [46]. Negative feedback loops have also been detected between genes whose expression is often dysregulated in cancer, which are both targets of the microRNAs and their negative regulators, as in the case of ADAM17 and NEDD9 with miR-145 in RCC and glioma cells, respectively [107,108], of Sox2, which downregulates the expression of the cluster [109], and of LimK1, a negative regulator of miR-143 in Non-Small Cells Lung Cancer (NSCLC) [100].

Recently, SILAC proteome combined with microarray analyses were performed in a colon cancer cell line upon re-expression of miR-143 and -145 at levels comparable to normal colon mucosa [14], allowing to identify downregulated proteins, 21 of which are shared targets [14]. Among these, CADHERIN (CDH) 17, FSCN1 and MOUSE DOUBLE MINUTE (MDM) 2 play important roles in tumor progression. In contrast, miR-143 or miR-145 overexpression in a human CRC cell line led to the downregulation of many components of apoptotic processes (i.e., SOD1, PRDX2 and PRDX6 for miR-143, and heat shock proteins, glutathione S-transferases and calreticulin for miR-145 [110]), suggesting miR-143-mediated cell survival.

\section{When the "Where" Matters: Tissue Specific Expression of microRNAs-143 and -145}

Emerging evidence underlines the functional relevance of the cellular context where the two microRNAs are expressed. In particular, Kent and colleagues reported that the downregulation of miRs-143 and -145 in cancer observed in many studies may not take into account the fact that bulk tumor tissue and not isolated cancer cells were analyzed. Indeed, in the normal colon both microRNAs are highly expressed in mesenchymal stromal cells like fibroblasts and smooth muscle cells and at very low levels in epithelial cells [111], while the ratio between stromal and tumor tissue is completely inverted in colonic tumors, as illustrated in Figure 3. This idea was confirmed by mouse studies, which showed that in the intestine miRs- 143 and -145 are expressed almost exclusively by mesenchymal cells, mainly smooth muscle cells and myofibroblasts, and are not detectable in the epithelial cells [25], in line with earlier studies [7,112]. Chivukula and colleagues demonstrated that, although miR-143 and -145 null mice did not display any defect in intestinal development, adult animals showed severely defective intestinal regeneration. Interestingly, the same phenotype could be reproduced by specific mesenchymal deletion of the microRNAs. Thus, miRs-143 and -145 play a crucial role in epithelial homeostasis and tissue repair in the intestine by regulating the functions of mesenchymal cells, in keeping with their originally described ability to stimulate VSMCs differentiation during blood vessel injury $[7,11,112,113]$. More recent data along this line show that TGF- $\beta$-induced miR-145 enhances myofibroblasts differentiation in both the lung and the skin, leading when excessive to lung fibrosis and hypertrophic scarring after wound healing [114,115].

In the context of cancer, it was shown that normal lung epithelium does not express either miR-143 or miR-145, and indeed their tumor-specific depletion did not enhance the development of lung adenocarcinoma in a genetic mouse model. In contrast, lung endothelial cells express high level of both microRNAs, which dramatically promote neo-angiogenesis and tumor formation [116,117]. In situ hybridization experiments on NSCLC patient samples showed higher miR-143 and -145 expression in both epithelial and stromal cells [118] from the tumor with respect to non-malignant lung tissue. In prostate cancer, in which miR-143 has been considered a tumor suppressor, recent microdissection studies reported the detection of very few copies of miR-143 in normal prostate epithelial cells as opposed to a very high expression in stromal cells [119]. In tumor specimens, stromal but not epithelial miR-143 expression decreased by 5 -fold. Also in breast cancer tissue, where microarray analysis showed downregulated expression of both microRNAs as compared to normal breast tissue, correlating with bad prognosis, in situ hybridization on the same samples allowed the detection of high microRNAs expression in stromal cells. Finally, miR-143 was shown to be highly expressed in the fibroblasts, but not in the tumor cells of aggressive scirrhous type gastric cancer, correlating with bad prognosis [120]. 
In keeping with previous data $[50,52,88]$, here miR-143 could positively regulate TGF- $\beta$ signaling, increasing SMAD2 phosphorylation and resulting in enhanced expression of collagen type III [120].

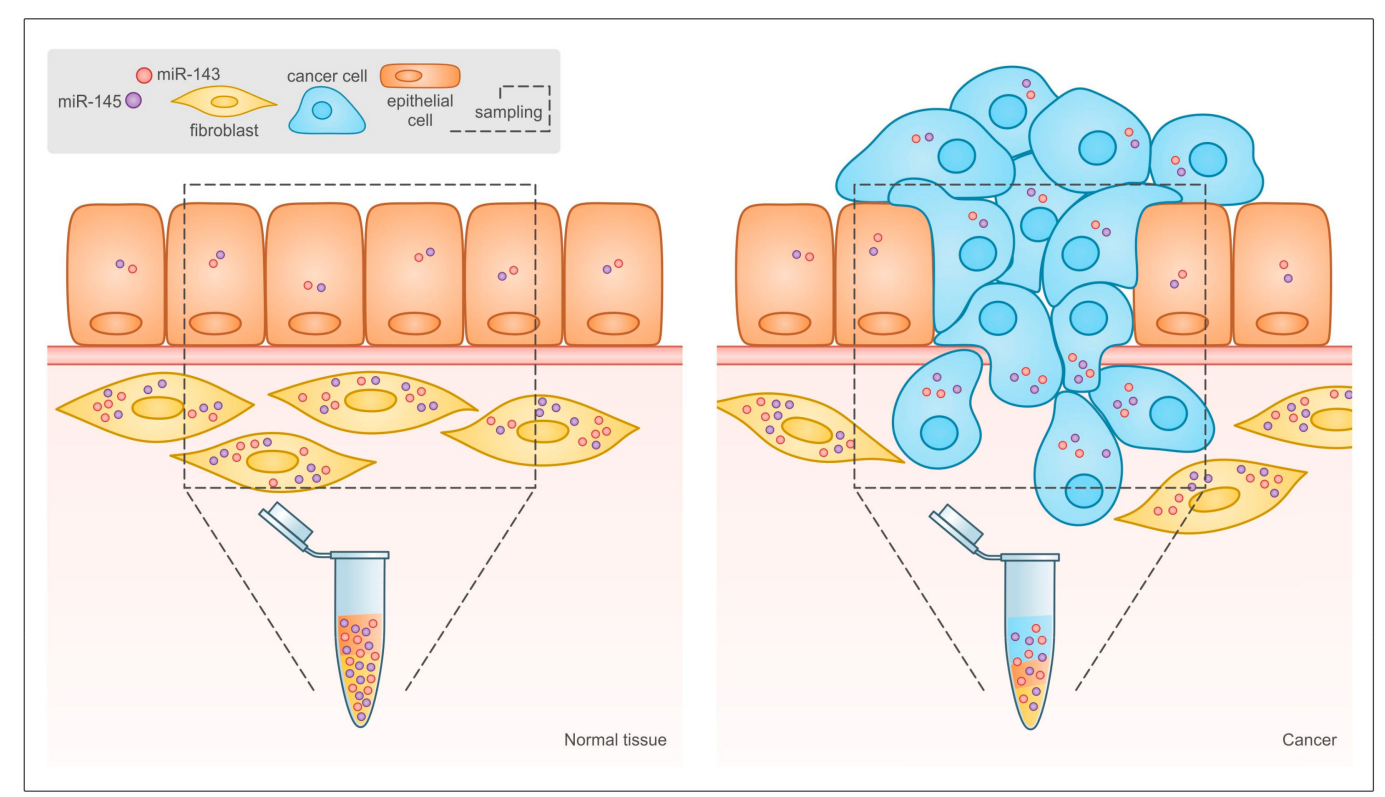

Figure 3. Relative abundance of different cell types in normal tissue and tumor may lead to misinterpretation of miR-143 and -145 expression data in solid tumors. In traditional bioptic samples, the amount of miR-143 and -145 that can be measured by RT-PCR is the result of their expression levels in the bulk of the tumor, including both cancer and stromal cells. As shown here, the expression of both microRNAs is much higher in stromal than in epithelial cells in normal tissues, and the relative abundance of the two cell types is inverted in tumors. This leads to reduced microRNA levels in the tumor bulk even when their expression is actually increased in tumor cells, and to the misleading conclusion that miR-143 and miR-145 are always down-regulated in tumors.

All of the above observations strongly support the idea put forward by Kent and co-authors [111], and call for a re- interpretation of earlier results. New expression data should be derived from micro-dissected tissue or by in situ hybridization to avoid biases due to the differential cell composition of normal and cancer tissues (Figure 3).

\section{Conclusions}

The data discussed above clearly show that miR-143 and -145 can exert both pro-oncogenic and anti-oncogenic functions, depending on a number of factors. First, the balance between the many different factors and signals that can positively or negatively regulate their as well as their targets expression in different cell types. Second, their cell-specific functions, which in turn may stem from their cell-specific expression and availability of their target genes. Indeed, the phenotypic consequences of their over-expression or silencing dramatically vary according to the cell type, the transformed status and even the stage of the disease, suggesting that these microRNAs are neither truly oncosuppressors or oncogenes, but rather they can both promote and inhibit tumorigenesis acting at several levels and in different cell types. More precise analysis of all tumor cell components and cell-specific overexpression or interference experiments are needed to shed light on the mechanisms dictating miR-143 and -145 dichotomic functions, for which animal models inactivating the microRNAs locus in different cell types would be of paramount importance. At this stage, this analysis discourages the proposed attempts at clinical intervention based on manipulating their expression/activity [6].

Funding: Work in the authors' laboratories is supported by grants from the Italian Cancer Research Association (AIRC IG16930), the Truus and Gerrit van Riemsdijk Foundation, Liechtenstein, and Italian Ministry of Education, 
University and Research (MIUR-PRIN 2017) to V.P. L.A. (id. 15073) and L.S. (id. 22628) were the recipients of Italian Cancer Research Foundation (FIRC) post-doctoral fellowships.

Conflicts of Interest: The authors declare no conflict of interest.

\section{References}

1. Hanahan, D.; Weinberg, R.A. Hallmarks of cancer: The next generation. Cell 2011, 144, 646-674. [CrossRef]

2. Lewis, B.P.; Burge, C.B.; Bartel, D.P. Conserved seed pairing, often flanked by adenosines, indicates that thousands of human genes are microRNA targets. Cell 2005, 120, 15-20. [CrossRef]

3. Friedman, R.C.; Farh, K.K.H.; Burge, C.B.; Bartel, D.P. Most mammalian mRNAs are conserved targets of microRNAs. Genome Res. 2009, 19, 92-105. [CrossRef]

4. Iorio, M.V.; Croce, C.M. MicroRNA involvement in human cancer. Carcinogenesis 2012, 33, 1126-1133. [CrossRef]

5. Orso, F.; Quirico, L.; Dettori, D.; Coppo, R.; Virga, F.; Ferreira, L.; Paoletti, C.; Baruffaldi, D.; Penna, E.; Taverna, D. Role of miRNAs in tumor and endothelial cell interactions during tumor progression. Semin. Cancer Biol. 2019. [CrossRef]

6. Das, A.V.; Pillai, R.M. Implications of miR cluster 143/145 as universal anti-oncomiRs and their dysregulation during tumorigenesis. Cancer Cell Int. 2015, 15, 92. [CrossRef]

7. Xin, M.; Small, E.; Sutherland, L.B.; Qi, X.; McAnally, J.; Plato, C.F.; Richardson, J.A.; Bassel-Duby, R.; Olson, E.N. MicroRNAs miR-143 and miR-145 modulate cytoskeletal dynamics and responsiveness of smooth muscle cells to injury. Genes Dev. 2009, 23, 2166-2178. [CrossRef] [PubMed]

8. Iio, A.; Nakagawa, Y.; Hirata, I.; Naoe, T.; Akao, Y. Identification of non-coding RNAs embracing microRNA-143/145 cluster. Mol. Cancer 2010, 9, 136. [CrossRef] [PubMed]

9. Sachdeva, M.; Zhu, S.; Wu, F.; Wu, H.; Walia, V.; Elble, R.; Watabe, K.; Mo, Y. p53 represses c-Myc through induction of the tumor suppressor miR-145. Proc. Natl. Acad. Sci. USA 2009, 106, 3207-3212. [CrossRef] [PubMed]

10. Xu, N.; Papagiannakopoulos, T.; Pan, G.; Thomson, J.A.; Kosik, K.S. MicroRNA-145 regulates OCT4, SOX2, and KLF4 and represses pluripotency in human embryonic stem cells. Cell 2009, 137, 647-658. [CrossRef] [PubMed]

11. Cordes, K.R.; Sheehy, N.T.; White, M.P.; Berry, E.C.; Morton, S.U.; Muth, A.N.; Lee, T.; Miano, J.M.; Ivey, K.N.; Srivastava, D. MiR-145 and miR-143 regulate smooth muscle cell fate and plasticity. Nature 2009, 460, 705-710. [CrossRef] [PubMed]

12. Long, X.; Miano, J.M. Transforming Growth Factor- 1 (TGF- 1) Utilizes Distinct Pathways for the Transcriptional Activation of MicroRNA 143/145 in Human Coronary Artery Smooth Muscle Cells. J. Biol. Chem. 2011, 286, 30119-30129. [CrossRef] [PubMed]

13. Elia, L.; Quintavalle, M.; Zhang, J.; Contu, R.; Cossu, L.; Latronico, M.V.G.; Peterson, K.L.; Indolfi, C.; Catalucci, D.; Chen, J.; et al. The knockout of miR-143 and -145 alters smooth muscle cell maintenance and vascular homeostasis in mice: Correlates with human disease. Cell Death Differ. 2009, 16, 1590-1598. [CrossRef] [PubMed]

14. Bauer, K.M.; Hummon, A.B. Effects of the miR-143/-145 microRNA Cluster on the Colon Cancer Proteome and Transcriptome. J. Proteome Res. 2012, 11, 4744-4754. [CrossRef]

15. Massagué, J. TGF $\beta$ signalling in context. Nat. Rev. Mol. Cell Biol. 2012, 13, 616-630. [CrossRef]

16. Low, E.L.; Baker, A.H.; Bradshaw, A.C. TGF $\beta$ smooth muscle cells and coronary artery disease: A review. Cell. Signal. 2019, 53, 90-101. [CrossRef]

17. Gays, D.; Hess, C.; Camporeale, A.; Ala, U.; Provero, P.; Mosimann, C.; Santoro, M.M. An exclusive cellular and molecular network governs intestinal smooth muscle cell differentiation in vertebrates. Development 2017, 144, 464-478. [CrossRef]

18. Akao, Y.; Nakagawa, Y.; Kitade, Y.; Kinoshita, T.; Naoe, T. Downregulation of microRNAs-143 and -145 in B-cell malignancies. Cancer Sci. 2007, 98, 1914-1920. [CrossRef]

19. Calin, G.A.; Sevignani, C.; Dumitru, C.D.; Hyslop, T.; Noch, E.; Yendamuri, S.; Shimizu, M.; Rattan, S.; Bullrich, F.; Negrini, M.; et al. Human microRNA genes are frequently located at fragile sites and genomic regions involved in cancers. Proc. Natl. Acad. Sci. USA 2004, 101, 2999-3004. [CrossRef] 
20. Derouet, M.F.; Liu, G.; Darling, G.E. MiR-145 Expression Accelerates Esophageal Adenocarcinoma Progression by Enhancing Cell Invasion and Anoikis Resistance. PLoS ONE 2014, 9, e115589. [CrossRef]

21. Zhang, X.; Liu, S.; Hu, T.; Liu, S.; He, Y.; Sun, S. Up-regulated microRNA-143 transcribed by nuclear factor kappa B enhances hepatocarcinoma metastasis by repressing fibronectin expression. Hepatology 2009, 50, 490-499. [CrossRef] [PubMed]

22. Yuan, W.; Sui, C.; Liu, Q.; Tang, W.; An, H.; Ma, J. Up-Regulation of MicroRNA-145 Associates with Lymph Node Metastasis in Colorectal Cancer. PLoS ONE 2014, 9, e102017. [CrossRef] [PubMed]

23. Wu, P.; Liang, J.; Yu, F.; Zhou, Z.; Tang, J.; Li, K. MiR-145 promotes osteosarcoma growth by reducing expression of the transcription factor friend leukemia virus integration 1. Oncotarget 2016, 7, 42241. [CrossRef] [PubMed]

24. Meulmeester, E.; Ten Dijke, P. The dynamic roles of TGF- $\beta$ in cancer. J. Pathol. 2011, 223, 205-218. [CrossRef] [PubMed]

25. Chivukula, R.R.; Shi, G.; Acharya, A.; Mills, E.W.; Zeitels, L.R.; Anandam, J.L.; Abdelnaby, A.A.; Balch, G.C.; Mansour, J.C.; Yopp, A.C.; et al. An Essential Mesenchymal Function for miR-143/145 in Intestinal Epithelial Regeneration. Cell 2014, 157, 1104-1116. [CrossRef]

26. Akao, Y.; Nakagawa, Y.; Hirata, I.; Iio, A.; Itoh, T.; Kojima, K.; Nakashima, R.; Kitade, Y.; Naoe, T. Role of anti-oncomirs miR-143 and -145 in human colorectal tumors. Cancer Gene Ther. 2010, 17, 398-408. [CrossRef]

27. Michael, M.Z.; O Connor, S.M.; van Holst Pellekaan, N.G.; Young, G.P.; James, R.J. Reduced accumulation of specific microRNAs in colorectal neoplasia. Mol. Cancer Res. 2003, 1, 882-891.

28. Ozen, M.; Creighton, C.J.; Ozdemir, M.; Ittmann, M. Widespread deregulation of microRNA expression in human prostate cancer. Oncogene 2008, 27, 1788-1793. [CrossRef]

29. Nam, E.J.; Yoon, H.; Kim, S.W.; Kim, H.; Kim, Y.T.; Kim, J.H.; Kim, J.W.; Kim, S. MicroRNA expression profiles in serous ovarian carcinoma. Clin. Cancer Res. 2008, 14, 2690-2695. [CrossRef]

30. Iorio, M.V.; Visone, R.; Di Leva, G.; Donati, V.; Petrocca, F.; Casalini, P.; Taccioli, C.; Volinia, S.; Liu, C.G.; Alder, H.; et al. MicroRNA signatures in human ovarian cancer. Cancer Res. 2007, 67, 8699-8707. [CrossRef]

31. Lin, T.; Dong, W.; Huang, J.; Pan, Q.; Fan, X.; Zhang, C.; Huang, L. MicroRNA-143 as a tumor suppressor for bladder cancer. J. Urol. 2009, 181, 1372-1380. [CrossRef] [PubMed]

32. Noguchi, S.; Yasui, Y.; Iwasaki, J.; Kumazaki, M.; Yamada, N.; Naito, S.; Akao, Y. Replacement treatment with microRNA-143 and -145 induces synergistic inhibition of the growth of human bladder cancer cells by regulating PI3K/Akt and MAPK signaling pathways. Cancer Lett. 2013. [CrossRef] [PubMed]

33. Corcoran, C.; Friel, A.M.; Duffy, M.J.; Crown, J.; O’Driscoll, L. Intracellular and Extracellular MicroRNAs in Breast Cancer. Clin. Chem. 2010, 57, 18-32. [CrossRef] [PubMed]

34. Iorio, M.V.; Casalini, P.; Piovan, C.; Braccioli, L.; Tagliabue, E. Breast cancer and microRNAs: Therapeutic impact. Breast 2012, 20, S63-S70. [CrossRef]

35. Wach, S.; Nolte, E.; Theil, A.; Stohr, C.; Rau, T.T.; Hartmann, A.; Ekici, A.; Keck, B.; Taubert, H.; Wullich, B. MicroRNA profiles classify papillary renal cell carcinoma subtypes. Br. J. Cancer 2013, 109, 714-722. [CrossRef]

36. Yamagata, T.; Yoshizawa, J.; Ohashi, S.; Yanaga, K.; Ohki, T. Expression patterns of microRNAs are altered in hypoxic human neuroblastoma cells. Pediatr. Surg. Int. 2010, 26, 1179-1184. [CrossRef]

37. Zhang, H.; Cai, X.; Wang, Y.; Tang, H.; Tong, D.; Ji, F. MicroRNA-143, down-regulated in osteosarcoma, promotes apoptosis and suppresses tumorigenicity by targeting Bcl-2. Oncol. Rep. 2010, 24, 1363-1369. [CrossRef]

38. Johannessen, C.; Moi, L.; Kiselev, Y.; Pedersen, M.I.; Dalen, S.M.; Braaten, T.; Busund, L. Expression and function of the miR-143/145 cluster in vitro and in vivo in human breast cancer. PLoS ONE 2017, 12, e0186658-22. [CrossRef]

39. Avgeris, M.; Mavridis, K.; Tokas, T.; Stravodimos, K.; Fragouilis, E.; Scorilas, A. Uncovering the clinical utility of miR-143, miR-145 and miR-224 for predicting the survival of bladder cancer patients following treatment. Carcinogenesis 2015, 36, 528-537. [CrossRef]

40. Puerta-Gil, P.; Garca-Baquero, R.; Jia, A.Y.; Ocaa, S.; Alvarez-Mgica, M.; Alvarez-Ossorio, J.L.; Cordon-Cardo, C.; Cava, F.; Sanchez-Carbayo, M. MiR-143, miR-222, and miR-452 are useful as tumor stratification and noninvasive diagnostic biomarkers for bladder cancer. Am. J. Pathol. 2012, 180, 1808-1815. [CrossRef]

41. Pignot, G.; Cizeron-Clairac, G.; Vacher, S.; Susini, A.; Tozlu, S.; Vieillefond, A.; Zerbib, M.; Lidereau, R.; Debre, B.; Amsellem-Ouazana, D.; et al. MicroRNA expression profile in a large series of bladder tumors: 
Identification of a 3-miRNA signature associated with aggressiveness of muscle-invasive bladder cancer. Int. J. Cancer 2013, 132, 2479-2491. [CrossRef] [PubMed]

42. Bearfoot, J.L.; Choong, D.Y.H.; Gorringe, K.L.; Campbell, I.G. Genetic analysis of cancer-implicated MicroRNA in ovarian cancer. Clin. Cancer Res. 2008, 14, 7246-7250. [CrossRef] [PubMed]

43. Suh, S.O.; Chen, Y.; Zaman, M.S.; Hirata, H.; Yamamura, S.; Shahryari, V.; Liu, J.; Tabatabai, Z.L.; Kakar, S.; Deng, G.; et al. MicroRNA-145 is regulated by DNA methylation and p53 gene mutation in prostate cancer. Carcinogenesis 2011, 32, 772-778. [CrossRef] [PubMed]

44. Xia, W.; Cheng, Q.; Wang, J.; Mao, Q.; Dong, G.; Shi, R.; Zheng, Y.Y.; Xu, L.; Jiang, F. DNA methylation mediated silencing of microRNA-145 is a potential prognostic marker in patients with lung adenocarcinoma. Sci. Rep. 2015, 5, 16901. [CrossRef] [PubMed]

45. Harada, K.; Baba, Y.; Ishimoto, T.; Kosumi, K.; Tokunaga, R.; Izumi, D.; Ohuchi, M.; Nakamura, K.; Kiyozumi, Y.; Kurashige, J.; et al. Suppressor microRNA-145 Is epigenetically regulated by promoter hypermethylation in esophageal squamous cell carcinoma. Anticancer Res. 2015, 35, 4617-4624. [PubMed]

46. Zhu, H.; Dougherty, U.; Robinson, V.; Mustafi, R.; Pekow, J.; Kupfer, S.; Li, Y.C.; Hart, J.; Goss, K.; Fichera, A.; et al. EGFR Signals Downregulate Tumor Suppressors miR-143 and miR-145 in Western Diet-Promoted Murine Colon Cancer: Role of G1 Regulators. Mol. Cancer Res. 2011, 9, 960-975. [CrossRef]

47. Kent, O.A.; Fox-Talbot, K.; Halushka, M.K. RREB1 repressed miR-143/145 modulates KRAS signaling through downregulation of multiple targets. Oncogene 2012, 32, 2576-2585. [CrossRef]

48. Szafranska, A.E.; Davison, T.S.; John, J.; Cannon, T.; Sipos, B.; Maghnouj, A.; Labourier, E.; Hahn, S.A. MicroRNA expression alterations are linked to tumorigenesis and non-neoplastic processes in pancreatic ductal adenocarcinoma. Oncogene 2007, 26, 4442-4452. [CrossRef]

49. Fan, X.; Chen, X.; Deng, W.; Zhong, G.; Cai, Q.; Lin, T. Up-regulated microRNA-143 in cancer stem cells differentiation promotes prostate cancer cells metastasis by modulating FNDC3B expression. BMC Cancer 2013, 13, 61. [CrossRef]

50. Avalle, L.; Incarnato, D.; Savino, A.; Gai, M.; Marino, F.; Pensa, S.; Barbieri, I.; Stadler, M.B.; Provero, P.; Oliviero, S.; et al. MicroRNAs-143 and -145 induce epithelial to mesenchymal transition and modulate the expression of junction proteins. Cell Death Differ. 2017, 24, 1750-1760. [CrossRef]

51. Barbieri, I.; Pensa, S.; Pannellini, T.; Quaglino, E.; Maritano, D.; Demaria, M.; Voster, A.; Turkson, J.; Cavallo, F.; Watson, C.J.; et al. Constitutively active Stat 3 enhances neu-mediated migration and metastasis in mammary tumors via upregulation of Cten. Cancer Res. 2010, 70, 2558-2567. [CrossRef] [PubMed]

52. Lam, J.; van Den Bosch, M.; Wegrzyn, J.; Parker, J.; Ibrahim, R.; Slowski, K.; Chang, L.; Martinez-Hoyer, S.; Condorelli, G.; Boldin, M.; et al. MiR-143/145 differentially regulate hematopoietic stem and progenitor activity through suppression of canonical TGF $\beta$ signaling. Nat. Commun. 2018, 9, 1-14. [CrossRef] [PubMed]

53. Arndt, G.M.; Dossey, L.; Cullen, L.M.; Lai, A.; Druker, R.; Eisbacher, M.; Zhang, C.; Tran, N.; Fan, H.; Retzlaff, K.; et al. Characterization of global microRNA expression reveals oncogenic potential of miR-145 in metastatic colorectal cancer. BMC Cancer 2009, 9, 117-153. [CrossRef] [PubMed]

54. Koo, S.; Martin, G.S.; Schulz, K.J.; Ronck, M.; Toussaint, L.G. Serial selection for invasiveness increases expression of miR-143/miR-145 in glioblastoma cell lines. BMC Cancer 2012, 12, 143. [CrossRef] [PubMed]

55. Koo, S.; Martin, G.; Toussaint, L.G. MicroRNA-145 Promotes the Phenotype of Human Glioblastoma Cells Selected for Invasion. Anticancer Res. 2015, 35, 3209-3215. [PubMed]

56. Ko, M.A.; Zehong, G.; Virtaten, C.; Guindi, M.; Waddell, T.K.; Keshavjee, S.; Darling, G.E. MicroRNA expression profiling of esophageal cancer before and after induction chemoradiotherapy. Ann. Thorac. Surg. 2012, 94, 1094-1103. [CrossRef] [PubMed]

57. Kano, M.; Seki, N.; Kikkawa, N.; Fujimura, L.; Hoshino, I.; Akutsu, Y.; Chiyomaru, T.; Enokida, H.; Nakagawa, M.; Matsubara, H. MiR-145, miR-133a and miR-133b: Tumor suppressive miRNAs target FSCN1 in esophageal squamous cell carcinoma. Int. J. Cancer J. Int. Cancer 2010, 127, 2804-2814. [CrossRef]

58. Liu, R.; Liao, J.; Yang, M.; Sheng, j.; Yang, H.; Wang, Y.; Pan, E.; Guo, W.; Pu, Y.; Kim, S.J.; et al. The cluster of miR-143 and miR-145 affects the risk for esophageal squamous cell carcinoma through co-regulating fascin homolog 1. PLoS ONE 2012. [CrossRef]

59. Zhang, H.-Y.; Zheng, S.-J.; Zhao, J.-H.; Zhao, W.; Zheng, L.-F.; Zhao, D.; Li, J.-M.; Zhang, X.-F.; Chen, Z.-B.; Yi, X.-N. MicroRNAs 144, 145, and 214 are down-regulated in primary neurons responding to sciatic nerve transection. Brain Res. 2011, 1383, 62-70. [CrossRef] 
60. Davis, B.N.; Hilyard, A.C.; Lagna, G.; Hata, A. SMAD proteins control DROSHA-mediated microRNA maturation. Nature 2008, 454, 56-61. [CrossRef]

61. Massagué, J. TGFbeta in Cancer. Cell 2008, 134, 215-230. [CrossRef] [PubMed]

62. Siegel, P.M.; Massagué, J. Cytostatic and apoptotic actions of TGF- $\beta$ in homeostasis and cancer. Nat. Rev. Cancer 2003, 3, 807-820. [CrossRef] [PubMed]

63. Salaroglio, I.C.; Gazzano, E.; Abdullrahman, A.; Mungo, E.; Castella, B.; Abd-Elrahman, G.E.F.A.E.; Massaia, M.; Donadelli, M.; Rubinstein, M.; Riganti, C.; et al. Increasing intratumor C/EBP- $\beta$ LIP and nitric oxide levels overcome resistance to doxorubicin in triple negative breast cancer. J. Exp. Clin. Cancer Res. 2018, 37, 286. [CrossRef] [PubMed]

64. Li, L.; Pan, X.; Li, Z.; Bai, P.; Jin, H.; Wang, T.; Song, C.; Zhang, L.; Gao, L. Association between polymorphisms in the promoter region of miR-143/145 and risk of colorectal cancer. Hum. Immunol. 2013, 74, 993-997. [CrossRef] [PubMed]

65. Yuan, F.; Sun, R.; Li, L.; Jin, B.; Wang, Y.; Liang, Y.; Che, G.; Gao, L.; Zhang, L. A functional variant rs353292 in the flanking region of miR-143/145 contributes to the risk of colorectal cancer. Sci. Rep. 2016, 6, 1-7. [CrossRef] [PubMed]

66. Chu, H.; Zhong, D.; Tang, J.; Li, J.; Xue, Y.; Tong, N.; Qin, C.; Yin, C.; Zhang, Z.; Wang, M. A functional variant in miR-143 promoter contributes to prostate cancer risk. Arch. Toxicol. 2016, 90, 403-414. [CrossRef] [PubMed]

67. Liang, Y.; Sun, R.; Li, L.; Yuan, F.; Liang, W.; Wang, L.; Nie, X.; Chen, P.; Zhang, L.; Gao, L. A Functional Polymorphism in the Promoter of MiR-143/145 Is Associated With the Risk of Cervical Squamous Cell Carcinoma in Chinese Women. Medicine 2015, 94, e1289. [CrossRef]

68. Wu, J.; Huang, Q.; Meng, D.; Huang, M.; Li, C.; Qin, T. A Functional rs353293 Polymorphism in the Promoter of miR-143/145 Is Associated with a Reduced Risk of Bladder Cancer. PLoS ONE 2016, 11, e0159115. [CrossRef]

69. Kang, Y.; Massagué, J. Epithelial-mesenchymal transitions: Twist in development and metastasis. Cell 2004, 118, 277-279. [CrossRef]

70. Thiery, J.P.; Acloque, H.; Huang, R.Y.J.; Nieto, M.A. Epithelial-mesenchymal transitions in development and disease. Cell 2009, 139, 871-890. [CrossRef]

71. He, Z.; Yi, j.; Liu, X.; Cheng, J.; Han, S.; Jin, L.; Chen, L.; Song, H. MiR-143-3p functions as a tumor suppressor by regulating cell proliferation, invasion and epithelial-mesenchymal transition by targeting QKI-5 in esophageal squamous cell carcinoma. Mol. Cancer 2016, 15, 51. [CrossRef] [PubMed]

72. Mei, L.-L.; Wang, W.-J.; Qiu, Y.-T.; Xie, X.-F.; Bai, J.; Shi, Z.-Z. MiR-145-5p Suppresses Tumor Cell Migration, Invasion and Epithelial to Mesenchymal Transition by Regulating the Sp1/NF-кB Signaling Pathway in Esophageal Squamous Cell Carcinoma. Int. J. Mol. Sci. 2017, 18, 1833. [CrossRef] [PubMed]

73. Zhao, H.; Kang, X.; Xia, X.; Wo, L.; Gu, X.; Hu, Y.; Xie, X.; Chang, H.; Lou, L.; Shen, X. MiR-145 suppresses breast cancer cell migration by targeting FSCN-1 and inhibiting epithelial-mesenchymal transition. Am. J. Transl. Res. 2016, 8, 3106-3114. [PubMed]

74. Zhai, L.; Ma, C.; Li, W.; Yang, S.; Liu, Z. miR-143 suppresses epithelial-mesenchymal transition and inhibits tumor growth of breast cancer through down-regulation of ERK5. Mol. Carcinog. 2015, 55, 1990-2000. [CrossRef] [PubMed]

75. Hu, H.; Xu, Z.; Li, C.; Xu, C.; Lei, Z.; Zhang, H.-T.; Zhao, J. MiR-145 and miR-203 represses TGF- $\beta$-induced epithelial-mesenchymal transition and invasion by inhibiting SMAD3 in non-small cell lung cancer cells. Lung Cancer 2016, 97, 87-94. [CrossRef] [PubMed]

76. Huang, H.; Sun, P.; Lei, Z.; Li, M.; Wang, Y.; Zhang, H.; Liu, J. MiR-145 inhibits invasion and metastasis by directly targeting Smad3 in nasopharyngeal cancer. Tumour Biol. 2015, 36, 4123-4131. [CrossRef]

77. Bufalino, A.; Cervigne, N.K.; de Oliveira, C.E.; Fonseca, F.P.; Rodrigues, P.C.; Macedo, C.C.S.; Sobral, L.M.; Miguel, M.C.; Lopes, M.A.; Leme, A.F.P.; et al. Low miR-143/miR-145 Cluster Levels Induce Activin A Overexpression in Oral Squamous Cell Carcinomas, Which Contributes to Poor Prognosis. PLoS ONE 2015, 10, e0136599. [CrossRef]

78. Peinado, H.; Olmeda, D.; Cano, A. Snail, Zeb and bHLH factors in tumour progression: An alliance against the epithelial phenotype? Nat. Rev. Cancer 2007, 7, 415. [CrossRef]

79. Gregory, P.A.; Bracken, C.P.; Bert, A.G.; Goodall, G.J. MicroRNAs as regulators of epithelial-mesenchymal transition. Cell Cycle 2008, 7, 3112-3117. [CrossRef] 
80. Gregory, P.A.; Bert, A.G.; Paterson, E.L.; Barry, S.C.; Tsykin, A.; Farshid, G.; Vadas, M.A.; Khew-Goodall, Y.; Goodall, G.J. The miR-200 family and miR-205 regulate epithelial to mesenchymal transition by targeting ZEB1 and SIP1. Nat. Cell Biol. 2008, 10, 593-601. [CrossRef]

81. Ren, D.; Wang, M.; Guo, W.; Huang, S.; Wang, Z.; Zhao, X.; Du, H.; Song, L.; Peng, X. Double-negative feedback loop between ZEB2 and miR-145 regulates epithelial-mesenchymal transition and stem cell properties in prostate cancer cells. Cell Tissue Res. 2014, 358, 763-778. [CrossRef] [PubMed]

82. Zhang, X.F.; Zhang, X.Q.; Chang, Z.X.; Wu, C.C.; Guo, H. MicroRNA-145 modulates migration and invasion of bladder cancer cells by targeting N-cadherin. Mol. Med. Rep. 2018, 17, 8450-8456. [CrossRef] [PubMed]

83. Peng, X.; Guo, W.; Liu, T.; Wang, X.; Tu, X.; Xiong, D. Identification of miRs-143 and -145 that Is Associated with Bone Metastasis of Prostate Cancer and Involved in the Regulation of EMT. PLoS ONE 2011, 6, e20341. [CrossRef] [PubMed]

84. Sathyanarayanan, A.; Chandrasekaran, K.S.; Karunagaran, D. MicroRNA-145 modulates epithelial-mesenchymal transition and suppresses proliferation, migration and invasion by targeting SIP1 in human cervical cancer cells. Cell. Oncol. 2017, 40, 119-131. [CrossRef]

85. Lei, H.; Gao, Y.; Xu, X. LncRNA TUG1 influences papillary thyroid cancer cell proliferation, migration and EMT formation through targeting miR-145. Acta Biochim. Biophys. Sin. 2017, 49, 588-597. [CrossRef]

86. Tan, J.; Qiu, K.; Li, M.; Liang, Y. Double-negative feedback loop between long non-coding RNA TUG1 and miR-145 promotes epithelial to mesenchymal transition and radioresistance in human bladder cancer cells. FEBS Lett. 2015, 589, 3175-3181. [CrossRef]

87. Xue, M.; Pang, H.; Li, X.; Li, H.; Pan, J.; Chen, W. Long non-coding RNA urothelial cancer-associated 1 promotes bladder cancer cell migration and invasion by way of the hsa-miR-145-ZEB1/2-FSCN1 pathway. Cancer Sci. 2016, 107, 18-27. [CrossRef]

88. Yang, S.; Cho, Y.J.; Jin, L.; Yuan, G.; Datta, A.; Buckhaults, P.; Datta, P. K An epigenetic auto-feedback loop regulates TGF- $\beta$ type II receptor expression and function in NSCLC. Oncotarget 2015, 6, 33237-33252. [CrossRef]

89. Tay, Y.; Rinn, J.; Pandolfi, P.P. The multilayered complexity of ceRNA crosstalk and competition. Nature 2014, 505, 344-352. [CrossRef]

90. Chen, Z.; Zeng, H.; Guo, Y.; Liu, P.; Pan, H.; Deng, A.; Hu, J. MiRNA-145 inhibits non-small cell lung cancer cell proliferation by targeting c-Myc. J. Exp. Clin. Cancer Res. 2010, 29, 151. [CrossRef]

91. Gregersen, L.H.; Jacobsen, A.B.; Frankel, L.B.; Wen, J.; Krogh, A.; Lund, A.H. MicroRNA-145 targets YES and STAT1 in colon cancer cells. PLoS ONE 2010, 5, e8836. [CrossRef] [PubMed]

92. Kent, O.A.; Chivukula, R.R.; Mullendore, M.; Wentzel, E.A.; Feldmann, G.; Lee, K.H.; Liu, S.; Leach, S.D.; Maitra, A.; Mendell, J.T. Repression of the miR-143/145 cluster by oncogenic Ras initiates a tumor-promoting feed-forward pathway. Genes Dev. 2010, 24, 2754-2759. [CrossRef] [PubMed]

93. Chen, X.; Guo, X.; Zhang, H.; Xiang, Y.; Chen, J.; Yin, Y.; Cai, X.; Wang, K.; Wang, G.; Ba, Y. Role of miR-143 targeting KRAS in colorectal tumorigenesis. Oncogene 2009, 28, 1385-1392. [CrossRef]

94. Xu, B.; Niu, X.; Zhang, X.; Tao, J.; Wu, D.; Wang, Z.; Li, P.; Zhang, W.; Wu, H.; Feng, N. MiR-143 decreases prostate cancer cells proliferation and migration and enhances their sensitivity to docetaxel through suppression of KRAS. Mol. Cell. Biochem. 2011, 350, 207-213. [CrossRef] [PubMed]

95. Wang, S.; Liu, J.C.; Ju, Y.J.; Pellecchia, G.; Voisin, V.; Wang, D.-Y.; Lehal, R.; Ben-David, Y.; Bader, G.D.; Zacksenhaus, E. MicroRNA-143/145 loss induces Ras signaling to promote aggressive Pten-deficient basal-like breast cancer. JCI Insight 2017, 2, e93313.

96. Clapé, C.; Fritz, V.; Henriquet, C.; Apparailly, F.; Fernandez, P.L.; Iborra, F.; Avancès, C.; Villalba, M.; Culine, S.; Fajas, L. MiR-143 Interferes with ERK5 Signaling, and Abrogates Prostate Cancer Progression in Mice. PLoS ONE 2009, 4, e7542. [CrossRef] [PubMed]

97. Takaoka, Y.; Shimizu, Y.; Hasegawa, H.; Ouchi, Y.; Qiao, S.; Nagahara, M.; Ichihara, M.; Lee, J.-D.; Adachi, K.; Hamaguchi, M.; et al. Forced Expression of miR-143 Represses ERK5/c-Myc and p68/p72 Signaling in Concert with miR-145 in Gut Tumors of ApcMin Mice. PLoS ONE 2012, 7, e42137. [CrossRef]

98. Zhou, L.L.; Dong, J.L.; Huang, G.; Sun, Z.L.; Wu, J. MicroRNA-143 inhibits cell growth by targeting ERK5 and MAP3K7 in breast cancer. Braz. J. Med. Biol. Res. 2017, 50, 5. [CrossRef]

99. Noguchi, S.; Mori, T.; Hoshino, Y.; Maruo, K.; Yamada, N.; Kitade, Y.; Naoe, T.; Akao, Y. MicroRNA-143 functions as a tumor suppressor in human bladder cancer T24 cells. Cancer Lett. 2011, 307, 211-220. [CrossRef] 
100. Xia, C.; Yang, Y.; Kong, F.; Kong, Q.; Shan, C. MiR-143-3p inhibits the proliferation, cell migration and invasion of human breast cancer cells by modulating the expression of MAPK7. Biochimie 2018, 147, 98-104. [CrossRef]

101. Shi, H.; Shen, H.; Xu, J.; Zhao, S.; Yao, S.Z.; Jiang, N. MiR-143-3p suppresses the progression of ovarian cancer. Am. J. Transl. Res. 2018, 10, 866.

102. Götte, M.; Mohr, C.; Koo, C.-Y.; Stock, C.; Vaske, A.-K.; Viola, M.; Ibrahim, S.A.; Peddibhotla, S.; Teng, Y.H.-F.; Low, J.-Y. MiR-145-dependent targeting of Junctional Adhesion Molecule A and modulation of fascin expression are associated with reduced breast cancer cell motility and invasiveness. Oncogene 2010, 29, 6569-6580. [CrossRef] [PubMed]

103. Anton, L.; DeVine, A.; Sierra, L.J.; Brown, A.G.; Elovitz, M.A. MIR-143 and miR-145 disrupt the cervical epithelial barrier through dysregulation of cell adhesion, apoptosis and proliferation. Sci. Rep. 2017, 7, 1-15. [CrossRef] [PubMed]

104. Feng, Y.; Zhu, J.; Ou, C.; Deng, Z.; Chen, M.; Huang, W.; Li, L. MicroRNA-145 inhibits tumour growth and metastasis in colorectal cancer by targeting fascin-1. Br. J. Cancer 2014, 110, 2300-2309. [CrossRef] [PubMed]

105. Gao, W.; Zhang, C.; Li, W.; Li, H.; Sang, J.; Zhao, Q.; Bo, Y.; Luo, H.; Zheng, X.; Lu, Y. Promoter Methylation-Regulated miR-145-5p Inhibits Laryngeal Squamous Cell Carcinoma Progression by Targeting FSCN1. Mol. Ther. 2019, 27, 365-379. [CrossRef]

106. Deacon, D.C.; Nevis, K.R.; Cashman, T.J.; Zhou, Y.; Zhao, L.; Washko, D.; Guner-Ataman, B.; Burns, C.G.; Burns, C.E. The MiR-143-adducin3 pathway is essential for cardiac chamber morphogenesis. Development 2010, 137, 1887-1896. [CrossRef]

107. Doberstein, K.; Steinmeyer, N.; Hartmetz, A.K.; Eberhardt, W.; Mittelbronn, M.; Harter, P.N.; Juengel, E.; Blaheta, R.; Pfeilschifter, J.; Gutwein, P. MicroRNA-145 targets the metalloprotease ADAM17 and is suppressed in renal cell carcinoma patients. Neoplasia 2013, 15, 218. [CrossRef]

108. Speranza, M.C.; Frattini, V.; Pisati, F.; Kapetis, D.; Porrati, P.; Eoli, M.; Pellegatta, S.; Finocchiaro, G. NEDD9, a novel target of miR-145, increases the invasiveness of glioblastoma. Oncotarget 2012, 3, 723. [CrossRef]

109. Fang, X.; Yoon, J.G.; Li, L.; Yu, W.; Shao, J.; Hua, D.; Zheng, S.; Hood, L.; Goodlett, D.R.; Foltz, G.; et al. The SOX2 response program in glioblastoma multiforme: An integrated ChIP-seq, expression microarray, and microRNA analysis. BMC Genom. 2011, 12, 11. [CrossRef]

110. Gomes, S.E.; Pereira, D.M.; Roma-Rodrigues, C.; Fernandes, A.R.; Borralho, P.M.; Rodrigues, C.M.P. Convergence of MIR-143 overexpression, oxidative stress and cell death in HCT116 human colon cancer cells. PLOS ONE 2018. [CrossRef]

111. Kent, O.A.; McCall, M.N.; Cornish, T.C.; Halushka, M.K. Lessons from miR-143/145: The importance of cell-type localization of miRNAs. Nucleic Acids Res. 2014, 42, 7528-7538. [CrossRef]

112. Boettger, T.; Beetz, N.; Kostin, S.; Schneider, J.; Krüger, M.; Hein, L.; Braun, T. Acquisition of the contractile phenotype by murine arterial smooth muscle cells depends on the Mir143/145 gene cluster. J. Clin. Investig. 2009, 119, 2634-2647. [CrossRef] [PubMed]

113. Cheng, Y.; Liu, X.; Yang, J.; Lin, Y.; Xu, D.-Z.; Lu, Q.; Deitch, E.A.; Huo, Y.; Delphin, E.S.; Zhang, C. MicroRNA-145, a novel smooth muscle cell phenotypic marker and modulator, controls vascular neointimal lesion formation. Circ. Res. 2009, 105, 158-166. [CrossRef] [PubMed]

114. Yang, S.; Cui, H.; Xie, N.; Icyuz, M.; Banerjee, S.; Antony, V.B.; Abraham, E.; Thannickal, V.J.; Liu, G. MiR-145 regulates myofibroblast differentiation and lung fibrosis. FASEB J. 2013, 27, 2382-2391. [CrossRef] [PubMed]

115. Gras, C.; Ratuszny, D.; Hadamitzky, C.; Zhang, H.; Blasczyk, R.; Figueiredo, C. MiR-145 contributes to hypertrophic scarring of the skin by inducing myofibroblast activity. Mol. Med. 2015, 21, 296-304. [CrossRef]

116. Dimitrova, N.; Gocheva, V.; Bhutkar, A.; Resnick, R.; Jong, R.M.; Miller, K.M.; Bendor, J.; Jacks, T. Stromal Expression of miR-143/145 Promotes Neoangiogenesis in Lung Cancer Development. Cancer Discov. 2016, 6, 188-201. [CrossRef]

117. Almeida, M.I.; Calin, G.A. The miR-143/miR-145 cluster and the tumor microenvironment: Unexpected roles. Genome Med. 2016, 8, 29. [CrossRef]

118. Skjefstad, K.; Johannessen, C.; Grindstad, T.; Kilvaer, T.; Paulsen, E.E.; Pedersen, M.; Donnem, T.; Andersen, S.; Bremnes, R.; Richardsen, E.; et al. A gender specific improved survival related to stromal miR-143 and miR-145 expression in non-small cell lung cancer. Sci. Rep. 2018, 8, 1-12. [CrossRef] 
119. Kumar, B.; Rosenberg, A.Z.; Choi, S.M.; Fox-Talbot, K.; De Marzo, A.M.; Nonn, L.; Brennen, W.N.; Marchionni, L.; Halushka, M.K.; Lupold, S.E. Cell-type specific expression of oncogenic and tumor suppressive microRNAs in the human prostate and prostate cancer. Sci. Rep. 2018, 8, 1-13. [CrossRef]

120. Naito, Y.; Sakamoto, N.; Oue, N.; Yashiro, M.; Sentani, K.; Yanagihara, K.; Hirakawa, K.; Yasui, W. MicroRNA-143 regulates collagen type III expression in stromal fibroblasts of scirrhous type gastric cancer. Cancer Sci. 2014, 105, 228-235. [CrossRef]

C 2020 by the authors. Licensee MDPI, Basel, Switzerland. This article is an open access article distributed under the terms and conditions of the Creative Commons Attribution (CC BY) license (http://creativecommons.org/licenses/by/4.0/). 